\title{
Penerapan Asuhan Keperawatan Jiwa Pada Ny.N Dengan Halusinasi Pendengaran
}

\author{
Mutia Mislika
}

$\underline{\text { Mutia.mislika17@gmail.com }}$

\section{BAB I \\ LATAR BELAKANG}

\subsection{Latar Belakang}

Skizofrenia yang berasal dari bahasa yunani yakni "Skhizein" yang dapat diartikan retak atau pecah (split), dan "phren" yang berarti pikiran, yang selalu dihubungkan dengan fungsi emosi. Dengan demikian seseorang yang mengalami skizofrenia adalah seseorang yang mengalami keretakan jiwa atau bisa dikatakan juga keretakan kepribadian serta emosi (Astari, 2020). Skizofrenia merupakan kondisi psikotik yang berpengaruh terhadap area fungsi individu termasuk berpikir, berkomunikasi, menerima, menafsirkan kenyataan, merasakan dan menunjukkan emosi serta penyakit kronis yag ditandai dengan pikiran kacau, delusi, halusinasi, dan perilaku aneh (Rhoads, 2011 dalam Pardede.2019).

Halusinasi merupakan keadaan seseorang mengalami perubahan dalam pola dan jumlah stimulasi yang diprakarsai secara internal atau eksternal disekitar dengan pengurangan, berlebihan, distorsi, atau kelainan berespon terhadap setiap stimulus (Pardede, Keliat, \& Yulia, 2015). Halusinasi pendengaran paling sering terjadi ketika klien mendengar suara-suara, suara tersebut dianggap terpisah dari pikiran klien sendiri. Isi suara-suara tersebut mengancam dan menghina, sering kali suara tersebut memerintah klien untuk melakukan tindakan yang akan melukai klien atau orang lain (Nyumirah, 2013).

Halusinasi dapat timbul pada pasien skizofrenia hebefrenik (Maharani, 2019) karena didapatkan data pasienyang mengatakan sering mendengar bisikan-bisikan suarayang menyuruhnya untuk marah-marah, pasien sering tertawa sendiri, pasien berbicara ngelantur, serta pasien lebih senang menyendiri dansikap pasien yang pemalu. Kondisi 
isi pikir dan arus pikir yang terdisorganisasi dan kemampuan kontak dengan kenyataan cenderung burukinidapat menimbulkan halusinasi(Ellina, 2012).

Skizofrenia adalah sekelompok reaksi psikotik yang memengaruhi berbagai area fungsi individu, termasuk berpikir, berkomunikasi, menerima, menginterpretasikan realitas, merasakan dan menunjukkan emosi. Menambahkan definisi skizofrenia yaitu penyakit kronis, parah, dan melumpuhkan, gangguan otak yang ditandai dengan pikiran kacau, waham, halusinasi, dan perilaku aneh (Pardede, Keliat, \& Yulia, 2015).

Merawat pasien skizofrenia dengan masalah halusinasi dibutuhkan pengetahuan, keterampilan dan kesabaran serta dibutuhkan waktu yang lama akibat kronisnya penyakit ini. Anggota keluarga yang bersama pasien skizofrenia menghabiskan lebih banyak waktu di rumah untuk merawat yang sakit dari pada memperhatikan dan mengurusi dirinya. Kemampuan dalam merawat pasien skizoprenia merupakan keterampilan yang harus praktis sehingga membantu keluarga dengan kondisi tertentu dalam pencapaian kehidupan yang lebih mandiri dan menyenangkan (Patricia et al, 2019).

Halusinasi merupakan gangguan penerimaan panca indra tanpa stimulasi eksternal seperti halusinasi pendengaran, penglihatan, pengecapan, penciuman, dan perabaan. Survei awal pada pembuatan askep pada skizofrenia ini dilakukan di desa Taujung, Aceh tenggara dengan jumlah pasien ada 2 orang tetapi yang menjadi subjek didalam pembuatan pembuatan askep ini berjumlah 1 orang dengan pasien Halusinasi pendengaran atas nama inisial Ny.N. penyebab Ny.N dijadikan sebagai subjek dikarekan pasien belum bisa mengatasi halusinasi pendengaran selain minum air putih dan minum obat. Maka tujuan asuhan keperawatan yang akan dilakukan ialah untuk mengajarkan standar pelaksanaan Halusinasi dan Ny.N mampu melaksanakannya tidak mendengarkan sesuatu yang membuat dia takut dan cemas.

\subsection{Rumusan Masalah}

Berdasarkan masalah yang telah di paparkan pada latar belakang maka rumusan masalah dalam askep ini yaitu Asuhan Keperawatan Halusinasi Pendengaran Ny.N di Desa Taujung, Aceh Tenggara. 


\subsection{Tujuan Penulisan}

\subsubsection{Tujuan Umum}

Mahasiswa mampu memberikan asuhan keperawatan jiwa pada Ny. $\mathrm{N}$ dengan Halusinasi Pendengan di desa Taujung, aceh tenggara.

\subsubsection{Tujuan Khusus}

1. Mahasiswa mampu mengetahui defenisi, tanda dan gejala, faktor penyebab, mekanisme koping penatalaksanaan pada pasien dengan Halusinasi

2. Mahasiswa mampu melakukan pengkajian pada pasien dengan Halusinasi.

3. Mahasiswa mampu menegakkan diagnosa atau masalah keperawatan pada Ny.N dengan Halusinasi

4. Mahasiswa mampu menetapkan intervensi keperawatan pada diagnosa Halusinasi.

5. Mahasiswa mampu melakukan tindakan keperawatan Halusinasi

6. Mahasiswa mampu megevaluasi sebagai tolak ukur guna menerapkan asuhan keperawatan dengan Halusinasi.

\subsection{Manfaat}

1. Responden

Diharapkan tindakan yang telah diajarkan dapat diterapkan secara mandiri untuk membantu dan mengontrol menghilangkan suara-suara yang didengar dan untuk mendukung kelangsungan kesehatan pasien.

2. Institusi pendidikan

Bagi institusi pendiidkan diharapkan untuk menjadi acuan dalam melakukan kegiatan mahasiswa dalam bidang keperawatan jiwa

3. Keluarga

Diharapkan keluarga dapat membantu dan acuan dalam menanganin anggota keluarga yang mengalami halusinasi. 


\section{BAB 2 \\ TINJAUAN TEORITIS}

\subsection{Konsep Halusinasi}

\subsubsection{Pengertian Halusinasi}

Halusinasi adalah salah satu gejala gangguan jiwa dimana klien mengalami perubahan sensori persepsi : merasakan sensori palsu berupa suara, penglihatan, pengecapan, perabaan atau penghidu ( Direja, 2011). Halusinasi adalah gangguan persepsi sensori tentang suatu objek atau gambaran dan pikiran yang sering terjadi tanpa adanya rangsangan dari luar yang dapat meliputi semua sistem penginderaan ( Dalami,2014). Halusinasi hilangnya kemampuan manusia dalam membedakan rangsangan internal (pikiran) dan rangsangan eksternal (dunia luar). Klien memberi persepsi atau pendapat tentang lingkungan tanpa ada objek atau rangsangan yang nyata (Kusumawati, 2012).

Halusinasi adalah salah satu gejala gangguan sensori persepsi yang dialami oleh pasien gangguan jiwa, klien merasakan sensasi berupa suara, penglihatan, pengecapan, perabaan, atau penghiduan tanpa stimulus nyata. (Keliat, 2014).Halusinasi pendengaran paling sering terjadi ketika klien mendengar suara -suara, halusinasi ini sudah melebur dan pasien merasa sangat ketakutan, panik dan tidak bisa membedakan antara khayalan dan kenyataan yang dialaminya (Hafizudiin, 2021).

Dari beberapa pengertian yang dikemukakan oleh para ahli mengenai halusinasi di atas, maka penulis dapat mengambil kesimpulan bahwa halusinasi adalah persepsi klien yang salah melalui panca indra terhadap lingkungan tanpa ada stimulus atau rangsangan yang nyata. sedangkan halusinasi pendengaran adalah kondisi di mana pasien mendengar suara, terutama suara-suara orang yang sedang membicarakan apa yang sedang dipikirkannya dan memerintahkan untuk melakukan sesuatu. 


\subsubsection{Etiologi}

Faktor predisposisi klien halusinasi menurut (Oktiviani, 2020) :

1. Faktor Predisposisi

a. Faktor perkembangan

Tugas perkembangan klien terganggu misalnya rendahnya kontrol dan kehangatan keluarga menyebabkan klien tidak mampu mandiri sejak kecil, mudah frustasi, hilang percaya diri.

b. Faktor sosiokultural

Seseorang yang merasa tidak diterima dilingkungan sejak bayi akan merasa disingkirkan, kesepian, dan tidak percaya pada lingkungan.

c. Biologis

Faktor biologis Mempunyai pengaruh terhadap terjadinya gangguan jiwa. Adanya stress yang berlebihan dialami seseorang maka didalam tubuh akan dihasilkan suatu zat yang dapat bersifat halusinogen neurokimia.Akibat stress berkepanjangan menyebabkan teraktivasinya neurotransmitter otak.

d. Psikologis

Tipe kepribadian lemah dan tidak bertanggung jawab mudah terjerumus pada penyalahgunaan zat adikitif. Hal ini berpengaruh pada ketidakmampuan klien dalam mengambil keputusan yang tepat demi masa depannya, klien lebih memilih kesenangan sesaat dan lari dari alam nyata menuju alam khayal.

e. Sosial Budaya

Meliputi klien mengalami interaksi sosial dalam fase awal dan comforting, klien meganggap bahwa hidup bersosialisasi di alam nyata sangat membahayakan. Klien asyik dengan Halusinasinya, seolah-olah ia merupakan tempat untuk memenuhi kebutuhan akan interaksi sosial, kontrol diri dan harga diri yang tidak didapatkan dakam dunia nyata.

2. Faktor Presipitasi

Faktor presipitasi merupakan stimulus yang dipersepsikan oleh individu sebagai tantangan, ancaman, atau tuntutan yang memerlukan energi ekstra untuk menghadapinya. Seperti adanya rangsangan dari lingkungan, misalnya partisipasi klien dalam kelompok, terlalu lama tidak diajak 
komunikasi, objek yang ada di lingkungan dan juga suasana sepi atau terisolasi, sering menjadi pencetus terjadinya halusinasi. Hal tersebut dapat meningkatkan stress dan kecemasan yang merangsang tubuh mengeluarkan zat halusinogenik. Penyebab Halusinasi dapat dilihat dari lima dimensi (Oktiviani, 2020) yaitu :

a. Dimensi fisik: Halusinasi dapat ditimbulkan oleh beberapa kondisi fisik seperti kelelahan yang luar biasa, penggunaaan obat-obatan, demam hingga delirium, intoksikasi alkohol dan kesulitan untuk tidur dalam waktu yang lama.

b. Dimensi Emosional: Perasaan cemas yang berlebihan atas dasar problem yang tidak dapat diatasi merupakan penyebab halusinasi itu terjadi. Isi dari halusinasi dapat berupa perintah memaksa dan menakutkan. Klien tidak sanggup lagi menentang perintah tersebut hingga dengan kondisi tersebut klien berbuat sesuatu terhadap ketakutan tersebut.

c. Dimensi Intelektual: Dalam dimensi intelektual ini menerangkan bahwa individu dengan halusinasi akan memperlihatkan adanya penurunan fungsi ego. Pada awalnya halusinasi merupakan usaha dari ego sendiri untuk melawan impuls yang menekan, namun merupakan suatu hal yang menimbulkan kewaspadaan yang dapat mengambil seluruh perhatian klien dan tidak jarang akan mengontrol semua perilaku klien.

d. Dimensi Sosial: Klien mengalami interaksi sosial dalam fase awal dan comforting, klien meganggap bahwa hidup bersosialisasi di alam nyata sangat membahayakan. Klien asyik dengan Halusinasinya, seolah-olah ia merupakan tempat untuk memenuhi kebutuhan akan interaksi sosial, kontrol diri dan harga diri yang tidak didapatkan dakam dunia nyata.

e. Dimensi Spiritual: Secara sepiritual klien Halusinasi mulai dengan kehampaan hidup, rutinitas tidak bermakna, hilangnya aktifitas ibadah dan jarang berupaya secara sepiritual untuk menyucikan diri. Saat bangun tidur klien merasa hampa dan tidak jelas tujuan hidupnya. Individu sering memaki takdir tetapi lemah dalam upaya menjemput rezeki, menyalahkan lingkungan dan orang lain yang menyebabkan takdirnya memburuk. 


\subsubsection{Tanda Dan Gejala}

Menurut Yuanita (2019). Tanda dan gejala Halusinasi terdiri dari :

a. Menarik diri dari orang lain, dan berusaha untuk menghindar diri dari orang lain

b. Tersenyum sendiri, tertawa sendiri

c. Duduk terpukau (berkhayal)

d. Bicara sendiri

e. Memandang satu arah, menggerakan bibir tanpa suara, penggerakan mata yang cepat, dan respon verbal yang lambat

f. Menyerang, sulit berhubungan dengan orang lain

g. Tiba-tiba marah,curiga, bermusuhan, merusak (diri sendiri, orang lain dan lingkungan) takut

h. Gelisah, ekspresi muka tegang, mudah tersinggung, jengkel,

i. Terjadi peningkatan denyut jantung, pernapasan dan tekanan darah

\subsubsection{Rentang Respon Halusinasi}

Halusinasi merupakan salah satu respon maldaptive individual yang berbeda rentang respon neurobiologi dalam Ini merupakan persepsi maladaptive. Jika klien yang sehat persepsinya akurat, mampu mengidentifisikan dan menginterpretasikan stimulus berdasarkan informasi yang diterima melalui panca indera (pendengaran, pengelihatan, penciuman, pengecapan dan perabaan) klien halusinasi mempersepsikan suatu stimulus panca indera walaupun stimulus tersebut tidak ada.Diantara kedua respon tersebut adalah respon individu yang karena suatu hal mengalami kelainan persensif yaitu salah mempersepsikan stimulus yang diterimanya, yang tersebut sebagai ilusi. Klien mengalami jika interpresentasi yang dilakukan terhadap stimulus panca indera tidak sesuai stimulus yang diterimanya,rentang respon tersebut sebagai berikut(Pardede,2021) 
Rentang Respon neurobiologis

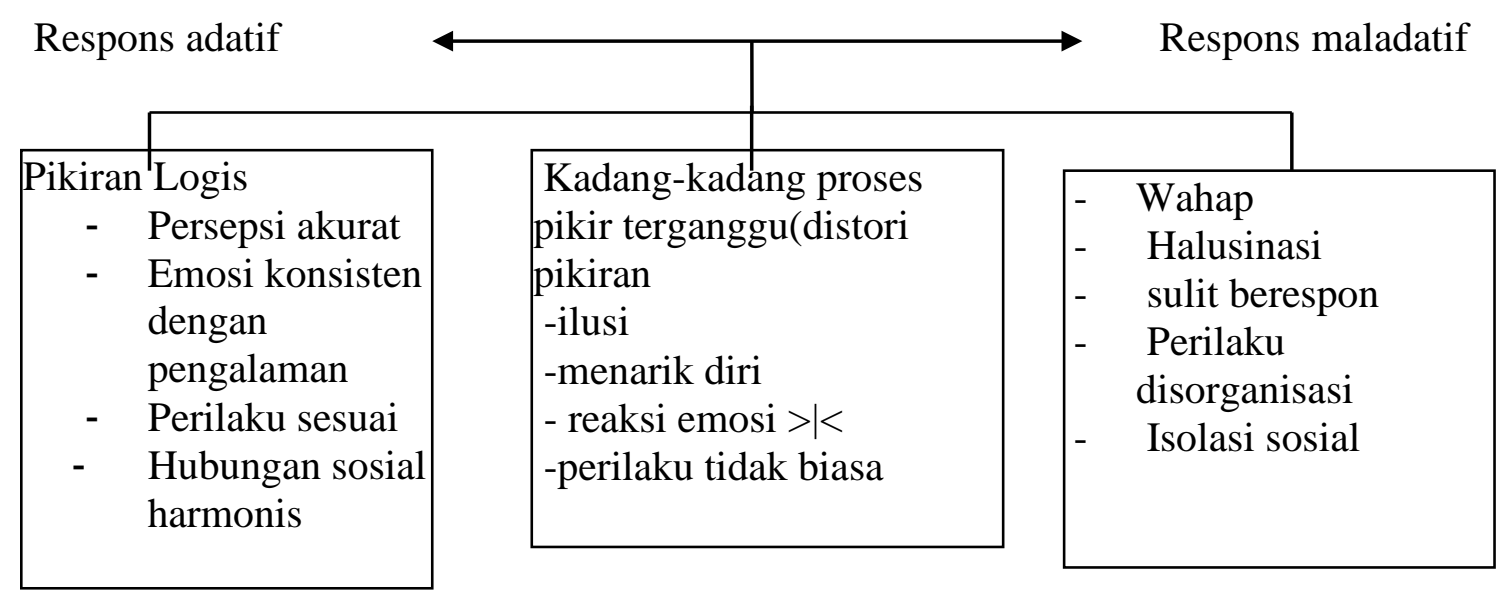

rentang respon neurobiologist halusinasi ( Muhith,2015).

1. Respon Adaptif

Respon adaptif adalah respon yang dapat diterima oleh norma-norma sosial budaya yang berlaku. Dengan kata lain individu tersebut dalam batas normal jika menghadapi suatu masalah akan dapat memecahkan masalah tersebut, respon adaftif :

a. Pikiran logis adalah pandangan yang mengarah pada kenyataan. Persepsi akurat adalah pandangan yang tepat pada kenyataan.

b. Emosi konsisten dengan pengalaman yaitu perasaan yang timbul dari pengalaman

c. Perilaku sosial adalah sikap dan tingkah laku yang masih dalam batas kewajaran.

d. Hubungan sosial adalah proses suatu interaksi dengan orang lain dan lingkungan.

2. Respon Maladaptif

Respon maladaptif adalah respon individu dalam menyelesaikan masalah yang menyimpang dari norma-norma sosial budaya dan lingkungan, adapun respon maladaptif meliputi:

a. Kelainan pikiran adalah keyakianan yang secara kokoh dipertahankan walaupun tidak diyakini oleh orang lain dan bertetangan dengan kenyataan sosial. 
b. Halusinasi merupakan persepsi sensori yang salah atau persepsi eksternal yang tidak realita atau tidak ada.

c. Kerusakan proses emosi adalah perubahan sesuatu yang timbul dari hati.

d. Perilaku tidak terorganisir merupakan suatu yang tidak teratur.

e. Isolasi sosial adalah kondisi kesendirian yang dialami oleh individu dan diterima sebagai ketentuan oleh orang lain dan sebagai suatu kecelakaan yang negatif mengancam.

\subsubsection{Jenis - Jenis Halusinasi}

Menurut (Pardede,2021), jenis halusinasi antara lain :

1. Halusinasi pendengaran (auditorik) $70 \%$

Karakteristik ditandai dengan mendengar suara, teruatama suara -suara orang, biasanya klien mendengar suara orang yang sedang membicarakan apa yang sedang dipikirkannya dan memerintahkan untuk melakukan sesuatu.

2. Halusinasi penglihatan(visual) $20 \%$

Karakteristik dengan adanya stimulus penglihatan dalam bentuk pancaran cahaya, gambaran geometrik, gambar kartun dan / atau panorama yang luas dan kompleks. Penglihatan bisa menyenangkan atau menakutkan.

3. Halusinasi penghidu (olfactory)

Karakteristik ditandai dengan adanya bau busuk, amis dan bau yang menjijikkan seperti: darah, urine atau feses.Kadang - kadang terhidu bau harum.Biasanya berhubungan dengan stroke, tumor, kejang dan dementia.

4. Halusinasi peraba(tactile)

Karakteristik ditandai dengan adanya rasa sakit atau tidak enak tanpa stimulus yang terlihat. Contoh : merasakan sensasi listrik datang dari tanah, benda mati atau orang lain.

5. Halusinasi pengecap(gustatory)

Karakteristik ditandai dengan merasakan sesuatu yang busuk, amis dan menjijikkan, merasa mengecap rasa seperti rasa darah, urin atau feses.

6. Halusinasi cenesthetik

7. Karakteristik ditandai dengan merasakan fungsi tubuh seperti darah mengalir melalui vena atau arteri, makanan dicerna atau pembentukan urine. 
8. Halusinasikinesthetic

Merasakan pergerakan sementara berdiri tanpa bergerak

Tabel 2.2 Karakteristik (Pardede,2021)

\begin{tabular}{|c|c|}
\hline Jenis Halusinasi & Karakteristik \\
\hline Pendengaran & $\begin{array}{l}\text { Mendengar suara - suara / kebisingan, paling } \\
\text { sering suara kata yang paling jelas, berbicara } \\
\text { dengan klien bahkan sampai kepercakapan } \\
\text { lengkap antara dua orang yang mengalami } \\
\text { halusinasi. Pikiran yang terdengar jelas dimana } \\
\text { klien mendengar perkataan bahwa klien disuruh } \\
\text { untuk melakukan sesuatu kadang - kadang dapat } \\
\text { membahayakan. }\end{array}$ \\
\hline Penglihatan & $\begin{array}{l}\text { Stimuluis visual dalam bentuk kelihatan cahaya, } \\
\text { gambaran geometris,gambaran kartun, bayangan } \\
\text { yang rumit dan kompleks. Bayangan bias } \\
\text { menyenangkan atau menakutkan seperti melihat } \\
\text { monster. }\end{array}$ \\
\hline Penghidu & $\begin{array}{l}\text { Menghirup bau-bauan tertentu seperti bau } \\
\text { darah,bau urin,atau bau feses,umumnya bau- } \\
\text { bauan yang tidak menyenangkan.Halusinasi } \\
\text { penghidu sering akibat dari stroke,tumor,kejang } \\
\text { atau dimensia. }\end{array}$ \\
\hline Pengecapan & $\begin{array}{l}\text { rasa mengecap rasa sesuatu seperti darah,urin atau } \\
\text { feses. }\end{array}$ \\
\hline Perabaan & $\begin{array}{l}\text { ngalami nyeri atau ketidaknyamanan tanpa } \\
\text { stimulus yang jelas.Rasa tersetrum listrik yang } \\
\text { datang dari tanah, benda mati atau oranglain. }\end{array}$ \\
\hline Sinestetik & $\begin{array}{l}\text { rasakan fungsi tubuh seperti aliran darah di vena } \\
\text { atau arteri,pencernaan makanan atau } \\
\text { pembentukan urin. }\end{array}$ \\
\hline Kinestetik & rasakan pergerakan saat berdiri tanpa bergerak. \\
\hline
\end{tabular}




\subsubsection{Fase-fase Halusinasi}

Halusinasi terbagi atas beberapa fase (Oktiviani, 2020):

a. Fase Pertama / Sleep disorder

Pada fase ini Klien merasa banyak masalah, ingin menghindar dari lingkungan, takut diketahui orang lain bahwa dirinya banyak masalah. Masalah makin terasa sulit karna berbagai stressor terakumulasi, misalnya kekasih hamil, terlibat narkoba, dikhianati kekasih, masalah dikampus, drop out, dst. Masalah terasa menekan karena terakumulasi sedangkan support sistem kurang dan persepsi terhadap masalah sangat buruk. Sulit tidur berlangsung trus-menerus sehingga terbiasa menghayal. Klien menganggap lamunanlamunan awal tersebut sebagai pemecah masalah

b. Fase Kedua / Comforting

Klien mengalami emosi yang berlanjut seperti adanya perasaan cemas, kesepian, perasaan berdosa, ketakutan, dan mencoba memusatkan pemikiran pada timbulnya kecemasan. Ia beranggapan bahwa pengalaman pikiran dan sensorinya dapat dia kontrol bila kecemasannya diatur, dalam tahap ini ada kecenderungan klien merasa nyaman dengan halusinasinya

c. Fase Ketiga / Condemning

Pengalaman sensori klien menjadi sering datang dan mengalami bias. Klien mulai merasa tidak mampu lagi mengontrolnya dan mulai berupaya menjaga jarak antara dirinya dengan objek yang dipersepsikan klien mulai menarik diri dari orang lain, dengan intensitas waktu yang lama.

\section{d. Fase Keempat / Controlling Severe Level of Anxiety}

Klien mencoba melawan suara-suara atau sensori abnormal yang datang. Klien dapat merasakan kesepian bila halusinasinya berakhir. Dari sinilah dimulai fase gangguan psikotik.

e. Fase ke lima / Conquering Panic Level of Anxiety

Pengalaman sensorinya terganggu. Klien mulai terasa terancam dengan datangnya suara-suara terutama bila klien tidak dapat menuruti ancaman atau perintah yang ia dengar dari halusinasinya. Halusinasi dapat berlangsung selama minimal empat jam atau seharian bila klien tidak mendapatkan komunikasi terapeutik. Terjadi gangguan psikotik berat. 


\subsubsection{Penatalaksanaan Halusinasi}

Penatalaksanaan pasien dengan halusinasi ada beberapa seperti farmakoterapi, terapi kejang listrik, psikoterapi dan rehabilitas yang diantaranya terapi okupasi, terapi sosial, TAK, terapi lingkungan (Prabowo,2014). Terapi okupasi aktivitas menggambar terhadap perubahan halusinasi pada pasien skizofrenia hasil penelitian menunjukan $\mathrm{p}=0,000$. Hasil tersebut menemukan adanya pengaruh terapi okupasi aktivitas menggambar terhadap perubahan halusinasi pada pasien skizofrenia Penelitian.

Aktivitas menanam yang dilakukan bertujuan untuk meminimalisasi interaksi pasien dengan dunianya yang tidak nyata, mengeluarkan pikiran, perasaan, ata emosi yang selama ini mempengaruhi perilaku yang tidak disadarinya, memberi motivasi dan memberikan kegembiraan, hiburan, serta mengalihkan perhatian pasien dari halusinasi yang dialami sehingga pikiran pasien tidak terfokus dengan halusinasinya khusus nya pada pasien halusinasi pendengaran (fitri, 2019).

\subsection{Konsep Dasar Asuhan Keperawatan}

\subsubsection{Pengkajian}

Pengkajian merupakan pengumpulan data subjektif dan objektif secara, sistematis dengan tujuan membuat penentuantindakan keperawatan bagi individu,kekuarga dan komunitas (Damayanti \& Iskandar,2014). Pada tahap ini ada beberapa yang perlu dieksplorasi baik pada klien yang berkenaan dengan kasus halusinasi yang meliputi :

a. Identitas klien

Meliputi nama klien, umur, jenis kelamin, status perkawinan, Agama, tanggal MRS, informan, tanggal pengkajian, nomor rumah klien, dan alamat klien.

b. Keluhan utama

Keluhan utama Biasanya berupa bicara sendiri, tertawa sendiri, senyum sendiri, menggerakkan bibir tanpa suara, menarik diri dari orang lain, tidak dapat membedakan yang nyata dan tidak nyata, ekspresi muka tegang mudah tersinggung, jengkel dan marah ketakutan biasa terdapat disorientasi waktu tempat dan orang, tidak dapat mengurus diri dan tidak melakukan kegiatan 
sehari-hari.

c. Faktor predisposisi

Faktor predisposisi adalah faktor resiko yang mempengaruhi jenis dan jumlah sumber yang dapat dibangkitkan oleh individu untuk mengatasi stres. Diperoleh baik dari klien maupun keluarganya, mengenai faktor perkembangan sosial kultural, biokimia psikologis dan genetik yaitu faktor resiko yang mempengaruhi jenis dan jumlah sumber yang dapat dibangkitkan oleh individu untuk mengatasi stres.

1. Faktor perkembangan ; biasanya tugas perkembangan mengalami hambatan dan hubungan interpersonal terganggu maka individu akan mengalami stres dan kecemasan.

2. Faktor sosiokultural ; berbagai faktor di masyarakat dapat menyebabkan seseorang merasa disingkirkan oleh kesepian terhadap lingkungan tempat klien dibesarkan.

3. Faktor biokimia ; adanya stres yang berlebihan dialami seseorang maka di dalam tubuh akan dihasilkan suatu zat yang dapat bersifat halusinogenik neuro kimia.

4. Faktor psikologis; hubungan interpersonal yang tidak harmonis, adanya peran ganda yang bertentangan dan tidak diterima oleh anak akan mengakibatkan stres dan kecemasan yang tinggi dan berakhir dengan gangguan orientasi realitas seperti halusinasi.

5. Faktor genetik; Apa yang berpengaruh dalam skizoprenia. Belum diketahui, tetapi Hasil studi menunjukkan bahwa faktor keluarga menunjukkan hubungan yang sangat berpengaruh pada penyakit ini.

\section{d. Faktor presipitasi}

Adanya rangsangan lingkungan yang sering yaitu seperti partisipasi klien dalam kelompok, terlalu lama Diajak komunikasi objek yang ada di lingkungan juga suasana sepi / isolasi adalah sering sebagai pencetus terjadinya halusinasi karena hal tersebut dapat meningkatkan stres dan kecemasan yang merangsang tubuh mengeluarkan zat halusinogenik. 


\section{e. Aspek fisik}

Hasil pengukuran tanda vital (TD, nadi, suhu, pernapasan, TB, BB) dan keluhan fisik yang dialami oleh klien. Terjadi peningkatan denyut jantung pernapasan dan tekanan darah.

f. Aspek psikososial

Genogram yang menggambarkan tiga generasi.

g. Konsep diri

1. Citra tubuh

Menolak melihat dan menyentuh bagian tubuh yang berubah/ tidak menerima perubahan tubuh yang terjadi / yang akan terjadi. Menolak penjelasan perubahan tubuh, persepsi negatif tentang tubuh. Preokupasi dengan bagian tubuh yang hilang, mengungkapkan keputusasaan, mengungkapkan ketakutan.

2. Identitas diri

Ketidakpastian memandang diri, sukar menetapkan keinginan dan tidak mampu mengambil keputusan.

3. Peran

Berubah / berhenti fungsi peran yang disebabkan penyakit, proses menua putus sekolah dan PHK.

4. Identitas diri

Mengungkapkan keputusasaan karena penyakitnya dan mengungkapkan keinginan yang terlalu tinggi

5. Harga diri

Perasaan malu terhadap diri sendiri, rasa bersalah terhadap diri sendiri, gangguan hubungan sosial, merendahkan martabat, mencederai diri dan kurang percaya diri.

h. Status mental

Pada pengkajian status mental pasien halusinasi ditemukan data berupa bicara sendiri, senyum sendiri, tertawa sendiri, menggerakkan bibir tanpa suara, pergerakan mata yang cepat, respon verbal yang lambat, menarik diri dari orang lain berusaha untuk menghindari orang lain, tidak dapat membedakan yang nyata dan tidak nyata, terjadi peningkatan denyut jantung pernapasan dan tekanan darah, perhatian dengan lingkungan yang kurang / 
hanya beberapa detik com berkonsentrasi dengan pengalaman sensori, sulit berhubungan dengan orang lain, ekspresi muka tegang, mudah tersinggung, jengkel dan marah tidak mampu mengikuti perintah dari perawat, tampak tremor dan berkeringat, perilaku panik, agitasi dan kataton curiga dan bermusuhan, bertindak merusak diri orang lain dan lingkungan, ketakutan, tidak dapat mengurus diri, biasa terdapat disorientasi waktu tempat dan orang.

i. Mekanisme koping

Apabila mendapat masalah, pasien takut / tidak mau menceritakan kepada orang lain (koping menarik diri). Mekanisme koping yang digunakan pasien sebagai usaha mengatasi kecemasan yang merupakan suatu kesepian nyata yang mengancam dirinya. Mekanisme koping yang sering digunakan pada halusinasi adalah :

1. Regresi : menjadi malas beraktivitas sehari-hari.

2. Proyeksi : menjelaskan perubahan suatu persepsi dengan berusaha untuk mengalihkan tanggung jawab kepada orang lain.

3. Menarik diri : sulit mempercayai orang lain dan asyik dengan stimulus internal.

j. Aspek medik

Terapi yang diterima klien bisa berupa terapi farmakologi psikomotor terapi okupasional, TAK dan rehabilitas.

\subsubsection{Diagnosa Keperawatan}

Menurut NANDA 2015 - 2017 yakni gangguan persepsi. Dengan faktor berhubungan dan batasan karakteristik disesuaikan dengan keadaan yang ditemukan pada tiap -tiap partisipan. Topik yang diteliti yakni kemampuan mengontrol halusinasi dengar (Hafizudiin,2021).

\subsubsection{Perencanaan Keperawatan}

Rencana tindakan pada keluarga (Husein,\& Arifin,2011)adalah;

1. Diskusikan masalah yang dihadap keluarga dalam merawat pasien 
2. Berikan penjelasan meliputi : pengertian halusinasi, proses terjadinya halusinasi, jenis halusinasi yang dialami, tanda dan gejala halusinasi, proses terjadinya halusinasi.

3. Jelaskan dan latih cara merawat anggota keluarga yang mengalami halusinasi : menghardik, minum obat, bercakap-cakap, melakukan aktivitas.

4. Diskusikan cara menciptakan lingkungan yang dapat mencegah terjadinya halusinasi.

5. Diskusikan tanda dan gejala kekambuhan

6. Diskusikan pemanfaatan fasilitas pelayanan kesehatan terdekat untukfollow upanggota keluarga dengan halusinasi.

Rencana tindakan keperawatan pada klien dengan diagnosa gangguan persepsi sensori halusinasi meliputi pemberian tindakan keperawatan berupa terapi (Sulah, Pratiwi,\& Teguh. 2016)yaitu :

1. Bantu klien mengenal halusinasinya meliputi isi, waktu terjadi halusinasi, isi, frekuensi, perasaan saat terjadi halusinasi respon klien terhadap halusinasi mengontrol halusinasi dengan cara menghardik.

2. Meminum obat secara teratur.

3. Melatih bercakap-cakap dengan orang lain.

4. Menyusunkegiatanterjadwal dan dengan aktifitas

\subsubsection{Implementasi Keperawatan}

Implementasi disesuaikan dengan rencana tindakan keperawatan. Adapun pelaksanaan tindakan keperawatan jiwa dilakukan berdasarkan Strategi Pelaksanaan (SP) yang sesuai dengan masing-masing masalah utama. Pada saat akan dilaksanakan tindakan keperawatan maka kontrak dengan klien dilaksanakan dengan menjelaskan apa yang akan dikerjakan dan peran serta klien yang diharapkan, dokumentasikan semua tindakan yang telah dilaksanakan serta respon klien (Hafizudiin,2021).

\subsubsection{Evaluasi Keperawatan}

Evaluasi adalah proses hasil atau sumatif dilakukan dengan membandingkan respon klien pada tujuan umum dan tujuan khusus yang telah ditentukan.halusinasi pendengaran tidak terjadi perilaku kekerasan, klien dapat 
membina hubungan saling percaya, klien dapat mengenal halusinasinya, klien dapat mengontrol halusinasi dengar dari jangka waktu 4x24 jam didapatkan data subjektif keluarga menyatakan senang karena sudah diajarkan teknik mengontrol halusinasi, keluarga menyatakan pasien mampu melakukan beberapa teknik mengontrol halusinasi. Data objektif pasien tampak berbicara sendiri saat halusinasi itu datang, pasien dapat berbincang - bincang dengan orang lain, pasien mampu melakukan aktivitas terjadwal, dan minum obat secara teratur (Hafizudiin,2021). 


\section{BAB 3 \\ ASUHAN KEPERAWATAN}

\subsection{Identitas Klien}

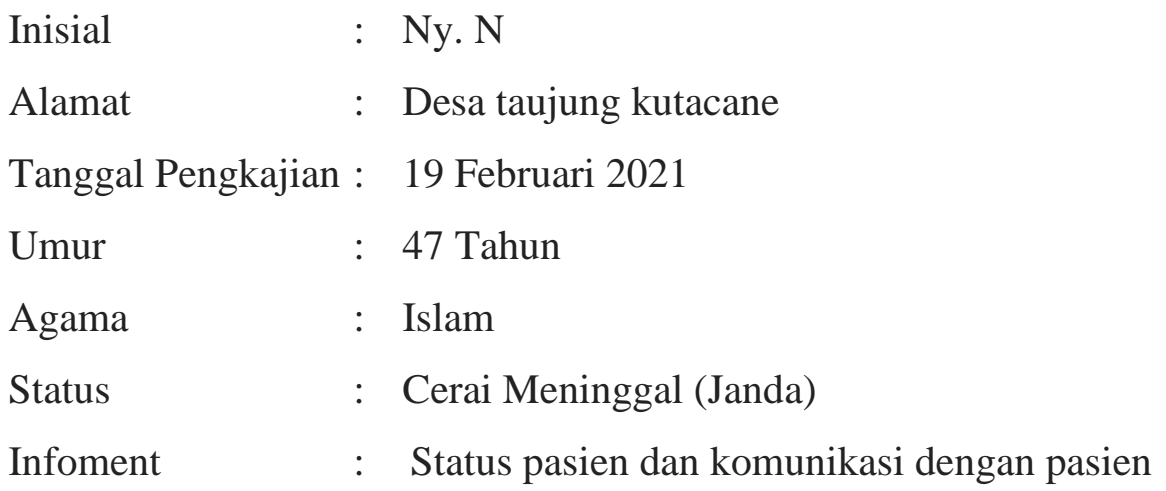

\subsection{Keluhan Utama}

Klien Awalnya marah-marah, mengganggu orang lain, susah tidur, dan suka keluyuran, hal ini dialami sejak 2 bulan dialaminya, klien juga tidak teratur minum obat. Klien mendengar suara-suara yang menyuruhnya untuk pergi dari rumah sebanyak $2 \mathrm{x}$ dalam sehari tanpa tujuan yang tidak jelas pada pagi dan sore hari, suara-suara itu muncul ketika klien menyadari ketika mau tidur malam. Saat suara itu muncul klien gelisah, dan menutupi telinganya dengan bantal.

Masalah Keperawatan : Gangguan Persepsi Sensori : Halusinasi Pendengaran.

\subsection{Faktor Predisposisi}

Klien sebelumnya pernah mengalami gangguan jiwa dan dirawat diRSJ,dan pulang kerumah dalam keadaan tenang. Dirumah klien tidak rutin minum obat, tidak mau kontrol ke salah satu poli jiwa di RS banda aceh. sehingga timbul gejala-gejala seperti diatas kemudian klien kambuh lagi. Klien awalnya marah-marah, mengganggu orang lain, susah tidur, dan suka keluyuran, hal ini dialami sejak 2 bulan dialaminya, klien juga tidak teratur minum obat, sehingga akhirnya keluarga membawa klien kembali ke poli jiwa dibanda aceh. Keluarga klien tidak ada yang pernah mengalami gangguan jiwa. Ny.N pertama kali di rawat di RSJ pada tahun 2020 dengan keluhan mudah marah-marah, pandangan tajam, tangan mengepal dan pernah melukai teman sekitar dan keluarga memutuskan untuk membawa klien ke Poli jiwa diBanda aceh. 


\subsection{Fisik}

Klien tidak memiliki keluhan fisik, saat dilakukan pemeriksaan tanda-tanda vital, didapatkan hasil TD : 130/80 mmHg ; $\mathrm{N}: 86 \mathrm{x} / \mathrm{i} ; \mathrm{S}: 36,5^{\circ} \mathrm{C}$; RR : 20x/i. Klien memiliki tinggi badan $165 \mathrm{~cm}$ dan berat badan $70 \mathrm{Kg}$.

\subsection{Psikososial}

\section{a. Genogram}

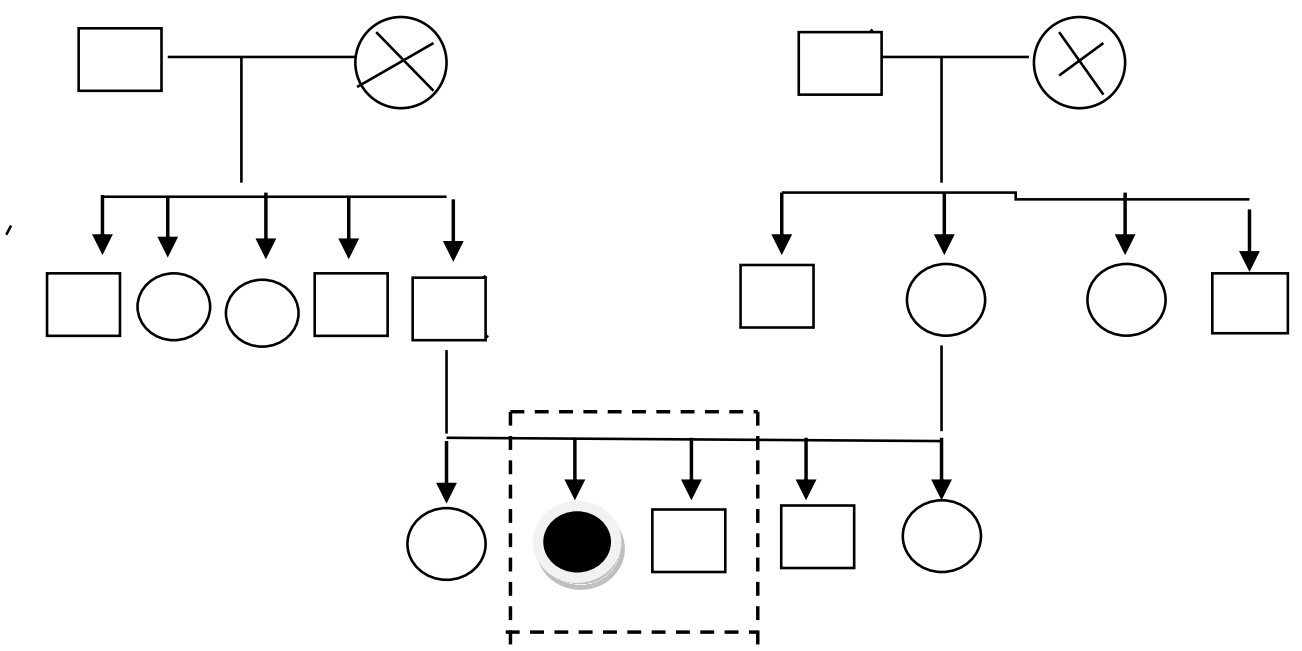

Klien merupakan anak kedua dari lima bersaudara, klien memiliki1 kakak dan 3 adik, Orang tua klien kedua-duanya sudah meninggal, klien tinggal satu rumah bersama anaknya.

Keterangan :

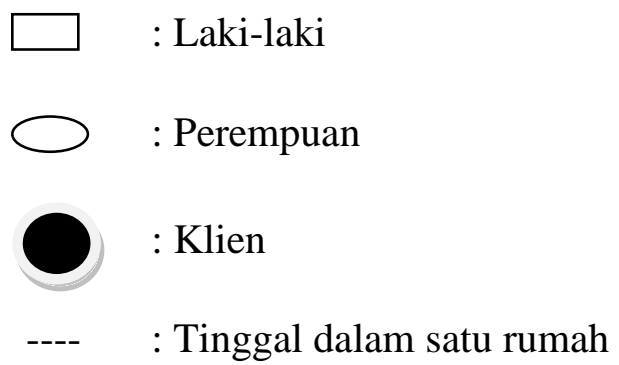

Penjelasan : pasien tinggal bersama adik laki - lakinya dengan alasan hanya adiknya yang mau mengurus kakaknya karena halusinasi pendengaran.

Masalah Keperawatan : Halusinasi Pendengaran 


\section{b. Konsep diri}
a. Gambaran diri
: Klien menyukai seluruh tubuhnya dan tidak
ada yang cacat.
b. Identitas
: Klien anak ke 2 dari 5 bersaudara.
c. Peran
: Klien hanya lulusan SMA yang saat ini tidak tidak memiliki pekerjaan.
d. Ideal diri $\quad$ Klien merasa merepotkan keluarga,klien ingin Cepat sembuh.
e. Harga diri : Klien merasa malu karena dia merasa dirinya Hanya menyusahkan keluarga.
Masalah keperawatan : Gangguan Konsep Diri : Harga Diri Rendah

\section{c. Hubungan sosial}

1. Orang yang berarti : orang yang berarti dalam kehidupan pasien adalah adik laki - lakinya dikarenakan adik laki -lakinya yang menjaga dan merawat pasien tersebut

2. Peran serta dalam kegiatan kelompok/masyarakat : Pasien mengatakan tidak mengikuti kegiatan di masyarakat tetapi mengikuti kegiatan beribadah bersama keluarganya.

3. Hambatan dalam berhubungan dengan orang lain : Pasien mengatakan susah berinteraksi di luar lingkungan karena diawasi dengan pihak keluarga. Tetapi untuk berinteraksi dengan keluarga pasien mengatakan tidak memiliki hambatan.

\section{d. Spiritual}

1. Nilai dan Keyakinan : Klien beragama islam dan yakin dengan agamanya.

2. Kegiatan Ibadah : sholat 5 waktu

\section{e. Status Mental}

1. Penampilan

Penjelasan : Klien berpenampilan bersih dan rapi

2. Pembicaraan

Penjelasan :Klien masih dapat menjawab pertanyaan perawat dengan lambat namun dapat dipahami

3. Aktivitas Motorik

Penjelasan : Klien tampak biasa saja dan santai

4. Suasana perasaan 
Penjelasan :Klien mengatakan sering merasa takut karena ada mendengar bisikan dari telinga kiri dan kanan

Masalah keperawatan : Halusinasi Pendengaran

5. Afek

Penjelasan :efek klien labil,suka diam

Masalah keperawatan : Isolasi sosial

6. Interaksi selama wawancara

Penjelasan :Klien kooperatif, ada kontak mata,tapi pandangan terlihat kosong pada lawan bicara,dan klien terlihat tenang dan mengikuti intruksi.

7. Persepsi

Penjelasan :Klien mengatakan Sering mendengar suara - suara disiang hari ketika sedang sendiri dan istirahat

Masalah keperawatan : Gangguan persepsi sensori : Halusinasi Pendengaran

8. Proses Pikir

Penjelasan : klien mampu menjawab apa yang ditanya dengan baik

9. Isi pikir

Penjelasan : Klien dapat mengontrol isi pikirnya klien tidak mengalami gangguan isi pikir dan tidak ada waham.

10. Memori

Penjelasan :Klien tidak mampu mengingat kejadian dimasa lalu dan dia tidak mampu mengulang pertemuan yang dilakukan therapy

11. Tingkat kesadaran

Penjelasan : Klien tidak mengalami gangguan orientasi, klien mengenali waktu,orang dan tempat

12. Tingkat konsentrasi berhitung :

Penjelasan : klien mampu berkonsentrasi dalam perhitungan sederhana tanpa bantuan orang lain.

13. Kemampuan penilaian

Penjelasan : Klien dapat membedakan hal yang baik dan yang buruk

14. Daya tilik diri

Penjelasan: Klien menyadari sakitnya dan sering mendengar suara - suara 


\subsection{Mekanisme Koping}

Klien mengalami mekanisme koping adaptif yaitu klien dapat berbicara baik dengan orang lain dan berkooperatif.

\subsection{Masalah Psikososial dan Lingkungan}

Klien mengatakan jarang mengikuti kegiatan dilingkungan rumah karena tidak diijinkan keluarganya,klien hanya mengikuti ketika ada acara keluarga bersama dirumah.

\subsection{Pengetahuan Kurang Tentang Gangguan Jiwa}

Klien mengetahui tentang gangguan jiwa dan klien paham tentang penyakitnya dan apa saja obat yang harus diminum dan kapan saja.

\subsection{Analisa Data}

\begin{tabular}{|c|c|c|}
\hline No & Analisa Data & Masalah keperawatan \\
\hline 1. & $\begin{array}{l}\text { DS: } \\
\text { - Keluarga klien mengatakan bahwa klien } \\
\text { sering berteriak - teriak di rumah } \\
\text { - Klien sering mendengarkan suara - suara } \\
\text { yang menyuruhnya untuk pergi } \\
\text { - } \text { Klien mengatakan suara -suara tersebut } \\
\text { muncul } 2 \text { kali/ hari, muncul pada saat pagi } \\
\text { setelah bangun tidur dan malam sebelum } \\
\text { tidur. } \\
\text { - Klien mengatkan suara itu muncul ketika } \\
\text { menyendiri dan kurang tidur malam } \\
\text { - Klien mengatakan ketika suara itu muncul dia } \\
\text { merasa gelisah } \\
\text { - Klien hanya menutup telinga ketika suara itu } \\
\text { muncul karena klien lupa cara untuk } \\
\text { meghardik } \\
\text { DO: } \\
\text { Klien sering marah - marah, mondar - mandir, }\end{array}$ & $\begin{array}{llr}\text { Gangguan } & \text { Persepsi } \\
\text { Sensori }: & \text { Halusinasi } \\
\text { Pendengaran } & \end{array}$ \\
\hline
\end{tabular}




\begin{tabular}{|c|c|c|}
\hline & $\begin{array}{l}\text { berbicara sendiri, berbicara ngawur, } \\
\text { sering senyum-senyum sendiri. }\end{array}$ & \\
\hline 2. & $\begin{array}{l}\text { DS: } \\
\text { - Klien mengatakan bahwa klien lebih senang } \\
\text { untuk menyendiri } \\
\text { - Klien mengatakan bahwa klien tidak diterima } \\
\text { di lingkungan sekitar nya } \\
\text { - } \text { Klien mengatakan tidak mampu untuk } \\
\text { berinteraksi dengan tetangganya. } \\
\text { DO: } \\
\text { - Tampak menyendiri dalam ruangan dan tidak } \\
\text { mampu berinteraksi dengan baik } \\
\text { - Klien tampak menarik diri dan susah untuk } \\
\text { berkomunikasi } \\
\text { - Klien tidak mampu untuk mengekpresikan } \\
\text { perasaan kesepian dan kontak mata tidak } \\
\text { tetap }\end{array}$ & $\begin{array}{l}\text { Isolasi Sosial: Menarik } \\
\text { Diri }\end{array}$ \\
\hline 3 & 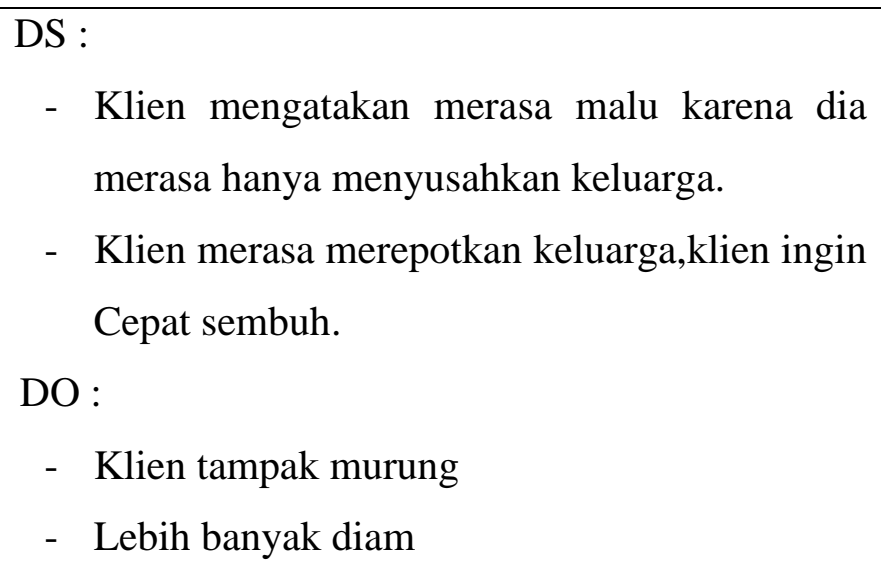 & $\begin{array}{l}\text { Gangguan Konsep Diri : } \\
\text { Harga Diri Rendah }\end{array}$ \\
\hline
\end{tabular}

\subsection{Daftar Masalah Keperawatan}

Gangguan Konsep Diri : Harga Diri Rendah Kronis

Gangguan Persepsi Sensori : Halusinasi Pendengaran

Isolasi Sosial : Menarik Diri 


\subsection{Pohon Masalah}

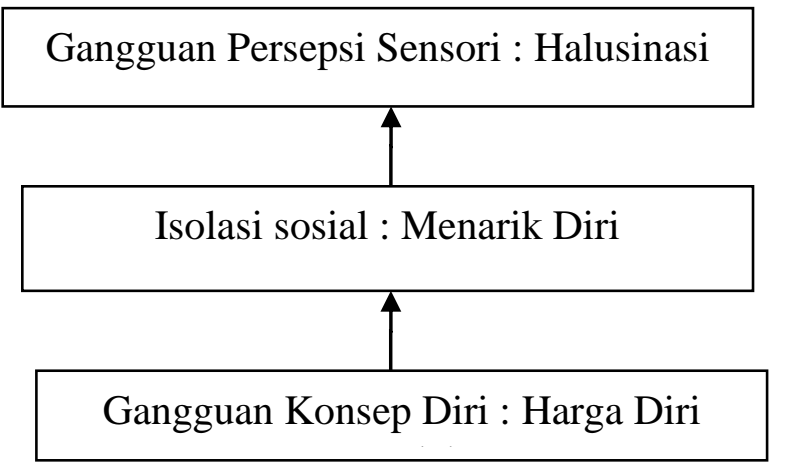

\subsection{Diagnosa Keperawatan}

Gangguan Persepsi Sensori : Halusinasi Pendengaran

\subsection{Intervensi Keperawatan}

\begin{tabular}{|c|c|c|}
\hline No & Diagnosa Keperawatan & Intervensi \\
\hline 1. & $\begin{array}{l}\text { Gangguan Persepsi Sensori } \\
\text { Halusinasi Pendengaran }\end{array}$ & $\begin{array}{l}\text { SP 1: } \\
\text { 1. Mengidentifikasi isi, frekuensi, } \\
\text { waktu terjadi, situasi pencetus, } \\
\text { perasaan daan respon halusinasi } \\
\text { 2. Mengontrol halusinasi dengan } \\
\text { menghardik } \\
\text { SP 2: } \\
\text { Mengontrol halusinasi dengan } \\
\text { minum obat secara teratur } \\
\text { SP 3: } \\
\text { Mengontrol halusinasi dengan } \\
\text { bercakap-cakap dengan orang lain } \\
\text { SP 4: } \\
\text { Mengontrol halusinasi dengan } \\
\text { melakukan kegiatan terjadwal }\end{array}$ \\
\hline 2. & Isolasi Sosial : Menarik Diri & $\begin{array}{l}\text { SP 1 : } \\
\text { Menjelaskan keuntungan dan } \\
\text { kerugian mempunyai teman } \\
\text { SP 2 : } \\
\text { Melatih klien berkenalan dengan } 2 \\
\text { orang atau lebih } \\
\text { SP 3 : } \\
\text { Melatih klien bercakap-cakap sambil } \\
\text { melakukan kegiatan harian } \\
\text { SP. 4 : } \\
\text { Melatih klien berbicara social : }\end{array}$ \\
\hline
\end{tabular}




\begin{tabular}{|l|l|l|}
\hline & $\begin{array}{l}\text { meminta sesuatu, berbelanja dan } \\
\text { sebagainya. }\end{array}$ \\
\hline
\end{tabular}

\subsection{Implementasi Dan Evaluasi}

\begin{tabular}{|c|c|c|}
\hline Hari/Tgl & Implementasi & Evaluasi \\
\hline $\begin{array}{l}\text { Jum'at, } 19 \\
\text { Februari } \\
2021 \\
\text { Jam } 14.00 \\
\text { Wib }\end{array}$ & $\begin{array}{l}\text { 1. Data: } \\
\text { - Klien sering mondar - mandir, berbicara } \\
\text { sendiri, berbicara ngawur, } \\
\text { sering senyum-senyum sendiri, sering } \\
\text { mengarahkan telinganya ke tempat - } \\
\text { tempat tertentu. } \\
\text { - Keluarga klien mengatakan bahwa klien } \\
\text { sering berbicara sendiri di rumah } \\
\text { - Klien sering mendengarkan suara - suara } \\
\text { yang menyuruhnya untuk pergi } \\
\text { - Klien mengatakan suara - suara tersebut } \\
\text { muncul } 2 \text { kali/ hari, } \\
\text { - Klien mengatakan suara itu muncul pada } \\
\text { pagi saat bangun tidur dan malam } \\
\text { - Klien mengatakan suara itu muncul saat } \\
\text { dia melamun dan menyendiri } \\
\text { - Klien merasa gelisah ketika suara-suara } \\
\text { itu muncul } \\
\text { - Klien hanya menutup telinga nya saat } \\
\text { suara itu muncul } \\
\text { 2. Diagnosa Keperawatan : } \quad \text { Gangguan } \\
\text { Persepsi Sensori : Halusinasi } \\
\text { Pendengaran } \\
\text { Tindakan Keperawatan : } \\
\text { SP 1 : Mengidentifikasi isi, frekuensi, } \\
\text { waktu terjadi, situasi pencetus, perasaan } \\
\text { dan respon halusinasi, mengontrol } \\
\text { halusinasi dengan menghardik. } \\
\text { - Mengidentifikasi jenis halusinasi } \\
\text { - Mengidentifikasi isi halusinasi } \\
\text { - Mengidentifikasi waktu halusinasi } \\
\text { Mengidentifikasi situasi } \\
\text { halusinasi pencetus } \\
\text { - Mengidentifikasi perasaan dan respon } \\
\text { halusinasi }\end{array}$ & 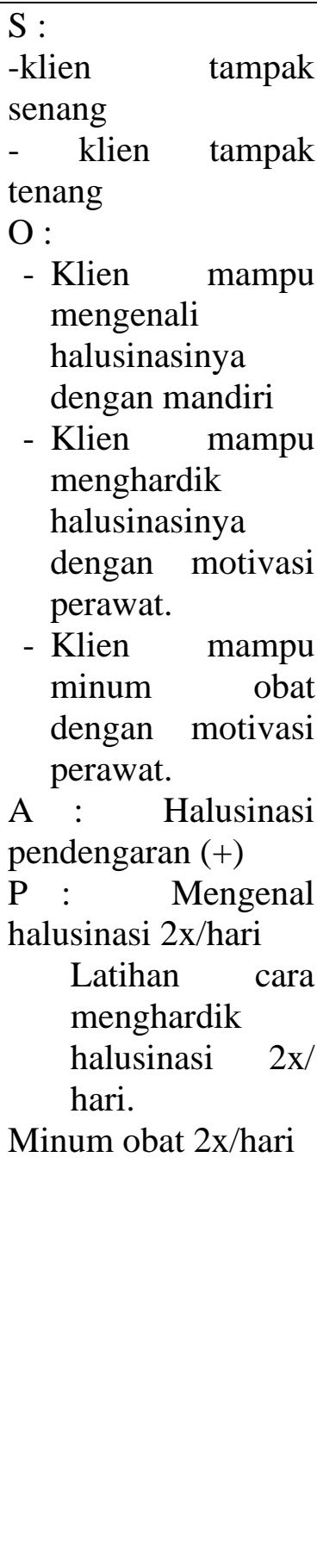 \\
\hline
\end{tabular}




\begin{tabular}{|c|c|c|}
\hline & $\begin{array}{l}\text { - Melatih cara mengontrol halusinasi } \\
\text { dengan menghardik } \\
\text { SP } 2 \text { : Mengontrol halusinasi dengan } \\
\text { minum obat secara teratur. } \\
\text { 4. Rencana Tindak Lanjut: } \\
\text { SP } 3 \text { : Mengontrol halusinasi dengan } \\
\text { bercakap - cakap dengan orang lain } \\
\text { SP } 4 \text { : Mengontrol halusinasi dengan } \\
\text { melakukan kegiatan tejadwal }\end{array}$ & \\
\hline $\begin{array}{l}\text { Sabtu, } 20 \\
\text { Februari } \\
2021 \\
\text { Jam } 18.00 \\
\text { Wib }\end{array}$ & 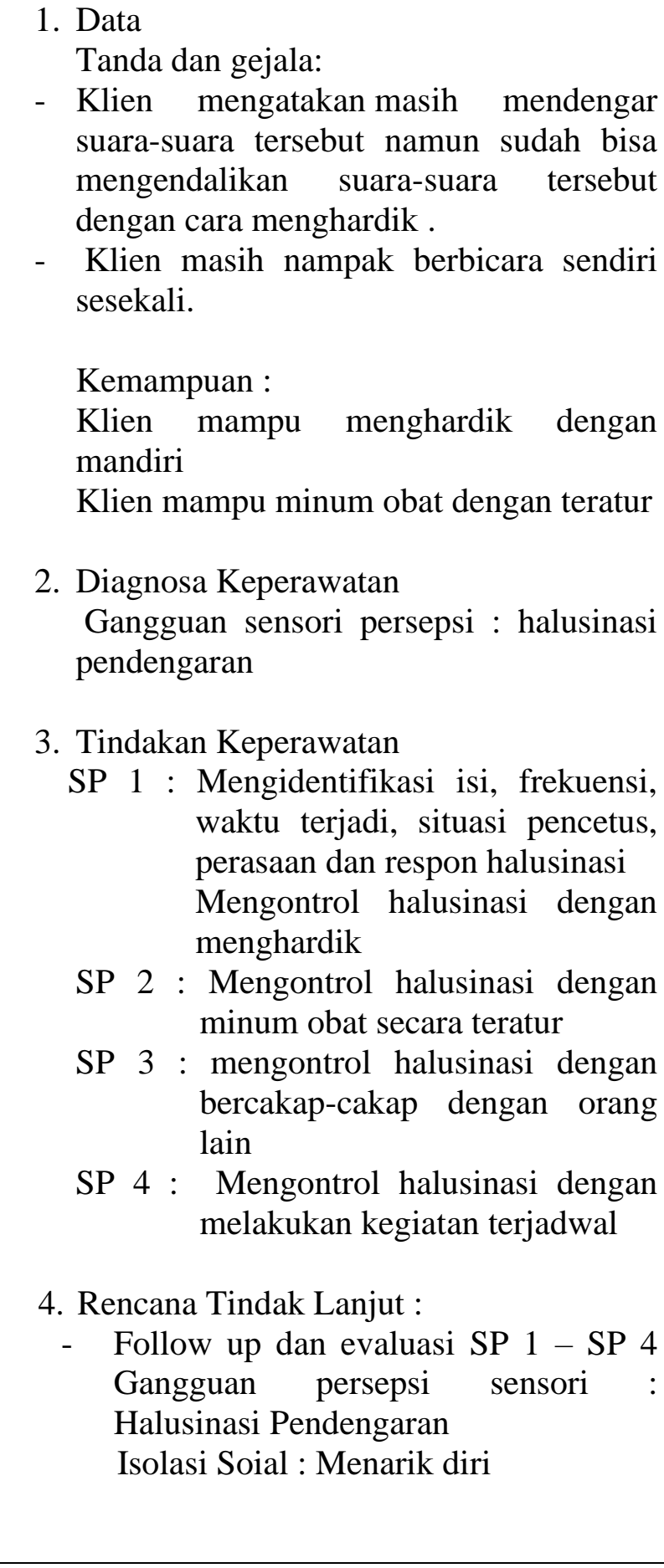 & 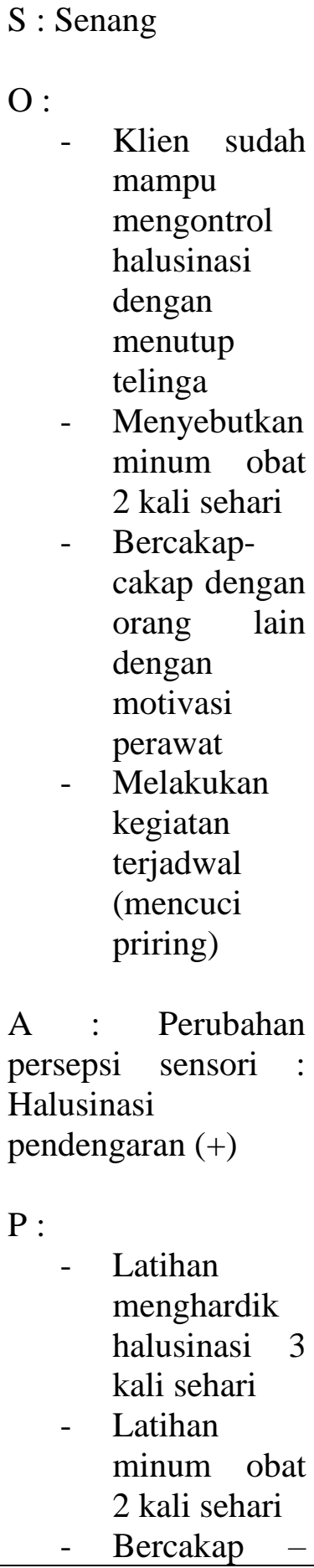 \\
\hline
\end{tabular}




\begin{tabular}{|c|c|c|}
\hline & & $\begin{array}{l}\text { cakap dengan } \\
\text { orang lain } \\
\text { 3x/hari } \\
\text { - Melakukan } \\
\text { kegiatan } \\
\text { terjadwal } \\
\text { 3/hari }\end{array}$ \\
\hline $\begin{array}{l}\text { Minggu, } 21 \\
\text { Februari } \\
2021 \\
\text { Jam } 14.30 \\
\text { Wib }\end{array}$ & $\begin{array}{l}\text { 1. Data } \\
\text { - Klien mengatakan bahwa klien lebih } \\
\text { senang untuk menyendiri } \\
\text { - Klien mengatakan tidak mampu untuk } \\
\text { berinteraksi dengan tetangganya. } \\
\text { - Tampak menyendiri dalam ruangan } \\
\text { dan tidak mampu berinteraksi dengan } \\
\text { baik } \\
\text { - Klien tampak menarik diri dan susah } \\
\text { untuk berkomunikasi } \\
\text { - Klien tidak mampu untuk } \\
\text { mengekpresikan perasaan kesepian } \\
\text { dan kontak mata tidak tetap. } \\
\text { 2. Diagnosa Keperawatan Isolasi Sosial : } \\
\text { Menarik Diri } \\
\text { 3. Tindaakan Keperawatan } \\
\text { SP } 1 \text { Menjelaskan keuntngan dan } \\
\text { kerugian mempunyai teman } \\
\text { SP } 2 \text { : Melatih klien berkenalan dengan } 2 \\
\text { orang atau lebih } \\
\text { 4. Rencana Tindak Lanjut : } \\
\text { SP } 3 \text { : Melatih klien bercakap-cakap } \\
\text { sambil melakukan kegiatan harian } \\
\text { SP } 4 \text { : Melatih klien berbicara social : } \\
\text { meminta sesuatu, bebelanjan dan } \\
\text { meminta sesuatu }\end{array}$ & 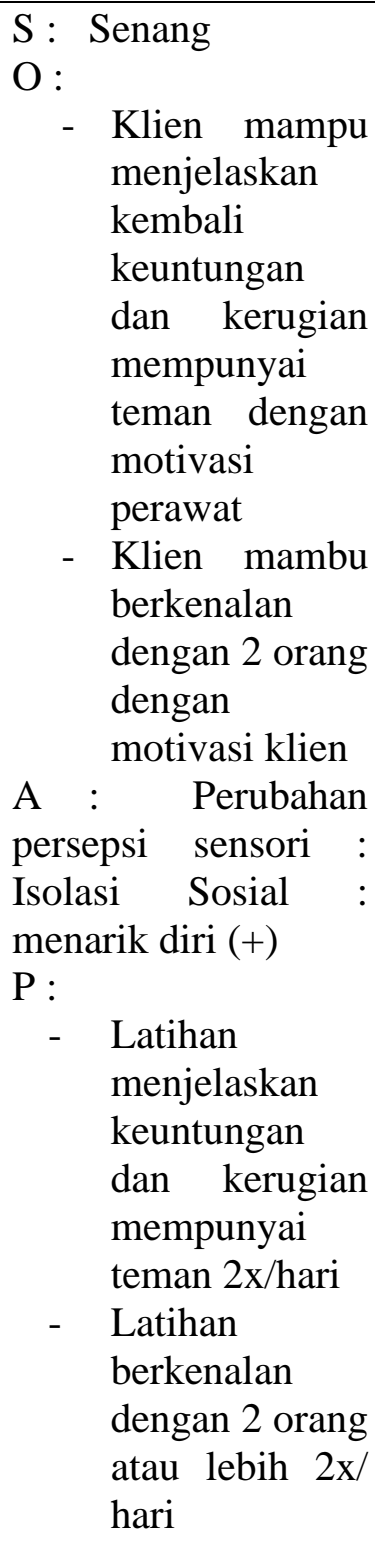 \\
\hline $\begin{array}{l}\text { Senin, } 22 \\
\text { Februari202 } \\
1 \\
\text { Jam } 18.00 \\
\text { Wib }\end{array}$ & $\begin{array}{l}\text { 1. Data } \\
\text { - Klien mengatakan bahwa klien sudah } \\
\text { mampu berinteraksi dengan orang lain } \\
\text { - Klien terlihat sudah tidak menyendiri } \\
\text { dan tidak murung } \\
\text { - Klien mampu untuk mengekspresikan } \\
\text { perasaan } \\
\text { Kemampuan : } \\
\text { Klien mampu menjelaskan keuntungan }\end{array}$ & 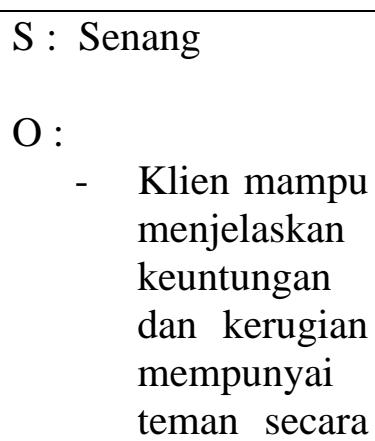 \\
\hline
\end{tabular}




\begin{tabular}{|c|c|}
\hline $\begin{array}{l}\text { dan kerugian memiliki teman } \\
\text { Klien mampu berkenalan dengan } 2 \text { orang } \\
\text { atau lebih } \\
\text { 2. Diagnosa Keperawatan } \\
\text { Isolasi Sosial: Menarik Diri } \\
\text { 3. Tindakan Keperawatan } \\
\text { SP } 3 \text { : Melatih klien bercakap-cakap } \\
\text { sambil melakukan kegiatan } \\
\text { harian } \\
\text { SP } 4 \text { : melatih klien berbicara social : } \\
\text { meminta sesuatu, berbelanja dan } \\
\text { sebagainya } \\
\text { 4. Rencana Tindak lanjut } \\
\text { - Follow up dan evaluasi SP } 1 \text { - SP } 4 \\
\text { Isolasi Sosial }\end{array}$ & 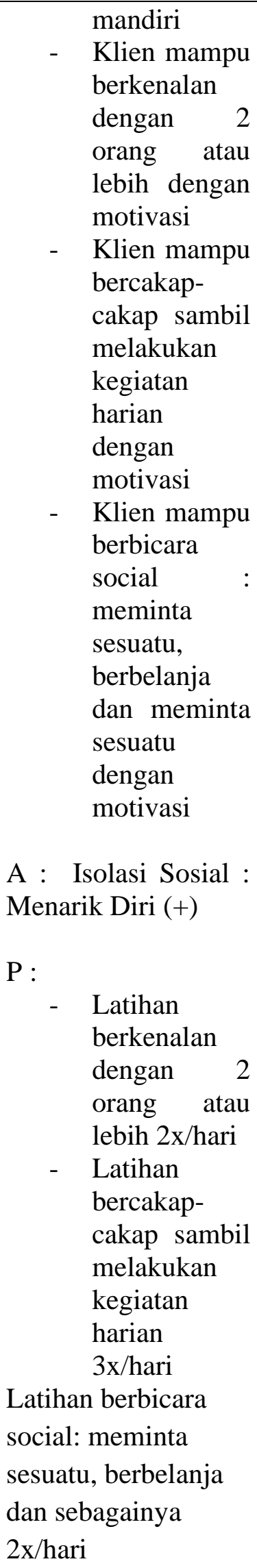 \\
\hline
\end{tabular}




\section{BAB 4 \\ PEMBAHASAN}

Setelah penulis melaksanakan asuhan keperawatan kepada $\mathrm{Ny} . \mathrm{N}$ dengan gangguan sensori persepsi: halusinasi pendengaran di Desa taujung kutacane, maka penulis pada BAB ini akan membahas kesenjangan antara teoritis dengan tinjauan kasus. Pembahasan dimulai melalui tahapan proses keperawatan yaitu pengkajian, diagnosa keparawatan, perencanaan, pelaksanaan dan evaluasi.

\subsection{Pengkajian}

Pada pembahasan ini diuraikan tentang hasil pelaksanaan tindakan keperawatan dengan pemberian terapi generalis pada klien halusinasi pendengaran. Pembahasan menyangkut analisis hasil penerapan terapi generalis terhadap masalah keperawatan halusinasi pendengaran. Tindakan keperawatan didasarkan pada pengkajian dan diagnosis keperawatan yang terdiri dari tindakan generalis yang dijabarkan sebagai berikut. Tahap pengkajian pada klien halusinasi dilakukan interaksi perawat-klien melalui komunikasi terapeutik untuk mengumpulkan data dan informasi tentang status kesehatan klien. Pada tahap ini terjadi proses interaksi manusia, komunikasi, transaksi dengan peran yang ada pada perawat sebagaimana konsep tentang manusia yang bisa dipengaruhi dengan adanya proses interpersonal.

Selama pengkajian dilakukan pengumpulan data dari beberapa sumber, yaitu dari pasien dan tenaga kesehatan di ruangan. Penulis mendapat sedikit kesulitan dalam menyimpulkan data karena keluarga pasien jarang mengunjungi pasien di rumah sakit jiwa. Maka penulis melakukan pendekatan kepada pasien melalui komunikasi terapeutik yang lebih terbuka membantu pasien untuk memecahkan perasaannya dan juga melakukan observasi kepada pasien. Adapun upaya tersebut yaitu:

a. Melakukan pendekatan dan membina hubungan saling percaya diri pada klien agar klien lebih terbuka dan lebih percaya dengan menggunakan perasaan.

b. Mengadakan pengkajian klien dengan wawancara

Dalam pengkajian ini, penulis menemukan kesenjangan karena ditemukan. Pada kasus Ny.N klien mendengar suara-suara aneh, mondar-mandir, tampak tegang, putus asa, sedih dan lain-lain. Gejala gejala yang muncul tersebut tidak semua mencakup dengan 
yang ada di teori klinis dari halusnasi (Keliat, dkk.2014). Akan tetapi terdapat faktor predisposisi maupun presipitasi yang menyebabkan kekambuhan penyakit yang dialami oleh Ny.N. Tindakan keperawatan terapi generalis yang dilakukan pada Ny.N adalah strategi pertemuan pertama sampai pertemuan empat. Strategi pertemuan pertama meliputi mengidentifikasi isi, frekuensi, jenis, dan respon klien terhadap halusinasi serta melatih cara menghardik halusinasi. Strategi pertemuan kedua yang dilakukan pada Ny.N meliputi melatih cara mengendalikan dengan bercakap-cakap kepada orang lain. Strategi pertemuan yang ketiga adalah menyusun jadwal kegiatan bersama-sama dengan klien. Strategi pertemuan keempat adalah mengajarkan dan melatih Ny.N cara minum obat yang teratur.

\subsection{Diagnosa Keperawatan}

Pada Teori Halusinasi (NANDA, 2015-2017), diagnosa keperawatan yang muncul sebanyak 3 diagnosa keperawatan (Aji, 2019) yang meliputi:

1. Halusinasi

2. Isolasi social

3. Harga diri rendah

Sedangkan pada kasus Ny.N ditemukan diagnosa keperawatan yang muncul yang meliputi: isolasi sosial, halusinasi. Dari hal tersebut di atas dapat dilihat terjadi kesamaan antara teori dan kasus. Dimana semua diagnosa pada teori muncul pada kasus Ny.N

\subsection{Intervensi}

Intervensi yang dilakukan padamasalah keperawatan gangguan sensori persepsi: halusinasipada penelitian ini menggunakan intervensi strategi pelaksanaan (SP) dan ditambah dengan intervensi inovasi terapipenerimaan dan komitment (acceptance and commitment therapy).Strategi pelaksanaan(SP) pada intervensi masalah keperawatan gangguan sensori persepsi: halusinasi dapat diimplementasikan secara keseluruhan kepada IbuS selama 4hari, hal ini didukung oleh klien telah kooperatif dalam menerima masukan/ intervensi yang diberikan oleh penulis. Begitu juga intervensi inovasi terapipenerimaan dan komitment (acceptance and commitment therapy)dapat diaplikasikan kepada klien salama 4hari. 
Intervensi inovasi dapat dilakukan sesuai SOP yang telah dibuat edangkan untuk intervensi keperawatan pada masalah keperawatan harga diri rendah kronik hanyadapat diimplementasikan kepada klienselama 2 harikarena penulis harus terus menerus mengulang tindakan keperawatan intervensi SP gangguan sensori persepsi: halusinasidan intervensi inovasi terapipenerimaan dan komitment (acceptance and commitment therapy) agar klien lebih memahami dan lebih bisa mengaplikasikan intervensi tersebut apabila klien mengalami halusinasi (Avidha,2018).

\subsection{Implementasi}

Implementasi atau disebut tindakan keperawatan merupakan rangkaian perilaku atau aktivitas yang dikerjakan oleh perawat untuk mengimplementasikan intervensi keperawatan. Tindakan-tindakan pada intervensi keperawatan terdiri atas observasi, terapeutik, edukasi dan kolaborasi (Fadhillah H, 2018). Pada tahap implementasi, penulis hanya mengatasi 1 masalah keperawatan yakni: diagnosa keperawatan halusinasi. Pada diagnosa keperawatan gangguan persepsi sensori halusinasi dilakukan strategi pertemuan yaitu mengidentifikasi isi, frekuensi, waktu terjadi, perasaan, respon halusinasi. Kemudian strategi pertemuan yang dilakukan yaitu latihan mengontrol halusinasi dengan cara menghardik. Strategi pertemuan yang kedua yaitu anjurkan minum obat secara teratur, strategi pertemuan yang ke tiga yaitu latihan dengan cara bercakap-cakap pada saat aktivitas dan latihan strategi pertemuan ke empat yaitu melatih klien melakukan semua jadwal kegiatan.

\subsection{Evaluasi}

Pada tinajauan teoritis evaluasi yang diharapkan adalah: Pasien mempercayai perawat sebagai terapis, pasien menyadari bahwa yang dialaminya tidak ada objeknya, dapat mengidentifikaasi halusinasi, dapat mengendalikan halusinasi melalui mengahrdik, latihan bercakap -cakap, melakukan aktivitas serta menggunakan obat secara teratur (Hafizudiin,2021). Pada tinjauan kasus evaluasi yang didapatkan adalah: Klien mampu mengontrol dan mengidentifikasi halusinasi, Klien mampu melakukan latihan bercakap-cakap dengan orang lain, Klien mampu melaksanakan jadwal yang telah dibuat bersama, Klien mampu memahami penggunaan obat yang benar:. Selain itu, dapat dilihat dari setiap evalusi yang dilakukan pada asuhan keperawatan, dimana terjadi penurunan gejala yang dialami oleh $\mathrm{Ny} . \mathrm{N}$ dari hari kehari selama proses interaksi. 


\section{BAB 5 \\ PENUTUP}

\subsection{Kesimpulan}

Berdasarkan uraian pada pembahasan di atas, maka penulis dapat disimpulkan bahwa:

1. Pengkajian dilakukan secara langsung pada klien dan juga dengan menjadikan status klien sebagai sumber informasi yang dapat mendukung data-data pengkajian. Selama proses pengkajian, perawat mengunakan komunikasi terapeutik serta membina hubungan saling percaya antara perawat-klien. Pada kasus Ny. N diperoleh bahwa klien mengalami gejala-gejala halusinasi seperti mendengar suara-suara, gelisah, sulit tidur, tampak tegang, mondar-mandir,tidak dapat mempertahankan kontak mata, sedih, malu, putus asa, menarik diri, mudah marah dan lain-lain. Faktor predisposisi pada Ny.N yaitu pernah mengalami gangguan jiwa sebelumnya.

2. Diagnosa keperawatan yang muncul pada kasus Ny.N Halusinasi pendengaran, isolasi sosial, koping individu inefektif, regimen teraupetik keluarga inefektif, harga diri rendah serta keputusasaan. Tetapi pada pelaksanaannya, penulis fokus pada masalah utama yaitu halusinasi pendengaran.

3. Perencanaan dan implementasi keperawatan disesuaikan dengan strategi pertemuan pada pasien halusinasi pendengaran dan isolasi sosial.

4. Evaluasi diperoleh bahwa terjadi peningkatan kemampuan klien dalam mengendalikan halusinasi yang dialami serta dampak pada penurunan gejala halusinasi pendengaran yang dialami.

\subsection{Saran}

1. Bagi Perawat

Diharapkan dapat menerapkan komunikasi terapeutik dalam pelaksanaan strategi pertemuan 1-4 pada klien dengan halusinasi sehingga dapat mempercepat proses pemulihan klien.

2. Bagi Pasien

Laporan ini diharapkan dapat menjadi acuan dan referensi dalam memberikan asuhan keperawatan pada klien dengan halusinasi pendengaran. 


\section{DAFTAR PUSTAKA}

Aji, W. M. H. (2019). Asuhan Keperawatan Orang Dengan Gangguan Jiwa Halusinasi Dengar Dalam Mengontrol Halusinasi. https://doi.org/10.31219/osf.io/n9dgs

Avidha, M., \& Fitriani, D. R. (2018). Analisis Praktik Klinik Keperawatan Jiwa pada Klien Gangguan Sensori Persepsi: Halusinasi dengan Intervensi Inovasi Terapi Penerimaan dan Komitmen (Acceptance And Comitment Therapy) Terhadap Tanda dan Gejala Halusinasi di Ruang Punai RSUD Atma Husada Mahakam Samarinda. https://dspace.umkt.ac.id//handle/463.2017/201

Damaiyanti \&Iskandar. (2014). Asuhan Keperawatan Jiwa. Bandung : Refika Aditama.

Dalami E, dkk. 2014. Asuhan Keperawatan Klien Dengan Gangguan Jiwa. Jakarta: CV. Trans Info Media.

Direja, Ade Herman Surya.2011. Buku Asuhan Keperawatan Jiwa. Yogyakarta: Nuha Medika.

Ellina, A. (2012). Pengaruh Terapi Aktifitas Kelompok (TAK) Stimulasi Persepsi Sessi 1-3 Terhadap Kemampuan Mengendalikan Halusinasi Pada Pasien Skizofrenia Hebefrenik. Strada Jurnal Ilmiah Kesehatan, 1(1), 56-62. Retrieved from https://sjik.org/index.php/sjik/article/view/22

Fadhillah H. 2018. Standar Intervensi Keperawatan Indonesia. Jakarta Selatan: DPP, PPNI http://repo.unikadelasalle.ac.id/index.php?p=show_detail\&id=12909

Fadli, S. M., \& Mitra, M. (2013). Pengetahuan dan Ekspresi Emosi Keluarga serta Frekuensi Kekambuhan Penderita Skizofrenia. Kesmas: National Public Health Journal, 7(10), 466-470. doi: http://dx.doi.org/10.21109/kesmas.v7i10.6

Fitri, N. Y. (2019). Pengaruh Terapi Okupasi terhadap Gejala Halusinasi Pendengaran Pada Pasien Halusinasi Pendengaran Rawat Inap di Yayasan Aulia Rahma Kemiling Bandar Lampung. Jurnal Kesehatan Panca Bhakti Lampung, 7(1), 33-40. https://doi.org/10.47218/jkpbl.v7i1.58

Hafizudiin. "Asuhan Keperawatan Jiwa Pada Tn.a Dengan Masalah Halusinasi Pendengaran." OSF Preprints, 15 Mar. 2021. Web. 10.31219/osf.io/9xn25

Keliat B, dkk. (2014). Proses Keperawatan Jiwa Edisi II. Jakarta : EGC.

Kusumawati, Farida dan Yudi Hartono. 2012. Buku Ajar Keperawatan Jiwa. Jakarta: Salemba Medika

Nyumirah, S. (2013). Peningkatan kemampuan interaksi sosial (kognitif, afektif dan perilaku) melalui penerapan terapi perilaku kognitif di $\mathrm{rsj} \mathrm{dr}$ amino gondohutomo 
semarang. Jurnal

keperawatan

jiwa, 1(2).https://doi.org/10.26714/jkj.1.2.2013.\%25p

Muhith, Abdul. (2015). Pendidikan Keperawatan Jiwa Teori Dan Aplikasi. Yogyakarta : CV Andi Offset

Oktiviani, D. P. (2020). Asuhan Keperawatan Jiwa Pada Tn. K dengan masalah Gangguan Persepsi Sensori: Halusinasi Pendengaran di Ruang Rokan Rumah Sakit Jiwa Tampan (Doctoral dissertation, Poltekkes $\quad$ Kemenkes Riau).http://repository.pkr.ac.id/id/eprint/498

Pardede, J. A, (2020). Ekspresi Emosi keluarga yang Merawat Pasien Skizofrenia. Jurnal $\begin{array}{lllll}\text { ilmiah keperawatan } & \text { Imelda, } & 6(2), & 117-\end{array}$ https://doi.org/10.2411/jikeperawatan.v6i2.403

Pardede, J. A., Keliat, B. A., \& Yulia, I. (2015). Kepatuhan dan Komitmen Klien Skizofrenia Meningkat Setelah Diberikan Acceptance And Commitment Therapy dan Pendidikan Kesehatan Kepatuhan Minum Obat. Jurnal Keperawatan Indonesia, 18(3), 157-166. https://doi.org/10.7454/jki.v18i3.419

Pardede, J. A. (2013). Pengaruh Acceptance And Commitment Therapy Dan Pendidikan Kesehatan Kepatuhan Minum Obat Terhadap Gejala, Kemampuan Berkomitmen Pada Pengobatan Dasar Kepatuhan Pasien Skizofrenia. https://www.researchgate.net/profile/Jek-Amidos/347011273.pdf

Pardede, J. A., Irwan, F., Hulu, E. P., Manalu, L. W., Sitanggang, R., \& Waruwu, J. F. A. P. (2021). Asuhan keperawatan Jiwa Dengan Masalah Halusinasi. 10.31219/osf.io/fdqzn

Patricia, H., Rahayuningrum, D. C., \& Nofia, V. R. (2019). Hubungan Beban Keluarga Dengan Kemampuan Caregiver Dalam Merawat Klien Skizofrenia. Jurnal Kesehatan Medika Saintika, 10(2), 45-52.doi: http://dx.doi.org/10.30633/jkms.v10i2.449

Prabowo, Eko. 2014. Konsep \& Aplikasi Asuhan Keperawatan Jiwa. Yogyakarta: Nuha Medika.

Riskesdas (2018) Hasil Utama riskesdas 2018 Kementrian Kesehatan Badan Penelitian dan Pengembangan Kesehatan. https://www.kemkes.go.id/resources/download/infoterkini/hasil-riskesdas-2018.pdf

Sulahyuningsih, E., Pratiwi, A., \& Teguh, S. (2016). Pengalaman Perawat Dalam Mengimplementasikan Strategi Pelaksanaan (Sp) Tindakan Keperawatan Pada Pasien Halusinasi Di Rumah Sakit Jiwa Daerah Surakarta (Doctoral dissertation, Universitas Muhammadiyah Surakarta). http://eprints.ums.ac.id/id/eprint/40858 
Who, (2019). Schizophrenia. Retrieved from. https://www.who.int/news-room/factsheets/\%20detail/schizophrenia

Yuanita, T. (2019). Asuhan Keperawatan Klien Skizofrenia Dengan Gangguan Persepsi Halusinasi Pendengaran Di Rsjd Dr. Arif Zainudin Solo Surakarta (Doctoral dissertation,Universitas Muhammadiyah http://eprints.umpo.ac.id/id/eprint/5381

Ponorogo). 